\title{
MUHAFAZAKÂR DÜŞÜNCEDE KADININ TOPLUMSAL KONUMU ${ }^{1}$ Yahya DEMIRKANOĞLU ${ }^{2}$
}

ÖZ

Her düşünce yapısında olduğu gibi, muhafazakâr düşünce de toplumsal öğelerin birçoğuna farklı boyutlarda az ya da çok tesirde bulunmaktadır. Bu düşünce yapısı içinde kadını diğer toplumsal öğelerden ayıran temel fark, muhafazakâr düşünce öğelerinin her birinin kadının toplumsal konumu üzerinde etkili olması, hatta büyük oranda bu konumu biçimlendirmesidir. Bu bağlamda muhafazakâr düşüncede kadının toplumsal konumunu ortaya çıkarmayı amaçlayan bu çalışma, üç ana bölüm olarak tasarlanmıştır. Birinci bölümde, muhafazakârlık kavramsal ve tarihsel açıdan; ikinci bölümde ise, öğeleri bakımından irdelenmeye çalışılmıştır. Son bölümde de söz konusu öğeler esas alınarak kadının toplumsal konumu, tarihsel ve betimsel araştırma yöntemlerinden yararlanılarak analiz edilmiştir. Çalışmanın sonunda, muhafazakâr düşüncede kadının toplumsal konumunun muhafazakârlığa ait din, gelenek, mülkiyet, aile ve düzen gibi öğeler etrafında şekillendiği; kadına atfedilen patriarkal rollerin, kadının kamusal alandaki görünürlügünü 'kadın tabiatıyla uyumlu' sınırlı bir alanla kısıtladığı sonucuna varılmıştır.

Anahtar Kelimeler: Muhafazakârlık, Kadın, Aile, Toplumsal Cinsiyet.

Jel Kodları: Z19, Y80.

\footnotetext{
${ }^{I}$ Bu çalışma 2015 'te tamamlanan "Türkiye'de Muhafazakâr Sağ ve Kadın: MSP'den AK Parti'ye Değişsen Siyasal Panorama" isimli doktora tezinden üretilmiştir.

${ }^{2} Y r d$. Doç. Dr. Bitlis Eren Üniversitesi, IIIBF, Kamu Yönetimi, yahyadmrkngl@hotmail.com Makale Gönderim Tarihi:15.09.2017; Makale Kabul Tarihi: 30.10.2017
} 


\title{
SOCIAL POSITION OF WOMEN IN CONSERVATIVE MENTALITY
}

\begin{abstract}
As it is the case in every mentality, conservative mentality also influences many of social elements in different dimensions more or less. In this mentality, the basic difference that differentiates the women from other social elements is the fact that each of the conservative mentality elements is influential on the social position of women and even shapes this position at a great deal. In this context, this study aims to reveal the social position of women in conservative mentality, and has been designed as three main parts. In the first part, conservative mentality is dealt with in conceptual and historical aspects; and in the second part, it is examined in terms of its elements. In the last part, the social position of women is analyzed based on the above-mentioned elements by making use of historical and descriptive research methods. At the end of the study, it was concluded that social position of women is shaped around religion, tradition, possession, family and order elements in conservative mentality; and the patriarchal roles referred to women limit the visibility of women in public areas with a field that is "consistent with the nature of women".
\end{abstract}

Keywords: Conservatism, Women, Family, Gender.

JEL Codes: Z19, Y80. 


\section{GİRIŞ̧}

Bir siyasi düşünce sistemi ve yaşam felsefesi olan muhafazakârlığın gelişip şekillenmesinde Aydınlanma Hareketi, Sanayi Devrimi ve Fransız Devrimi etkili olmuştur. Her üç olgunun meydana getirmek istediği değişime karşı bir tepki hareketi olan muhafazakârlık, mevcut olan toplumsal düzenin devamlılığından yana bir tavır içerisinde olmuştur. Edmund Burke’un fikirleri çerçevesinde şekillenen ve organik bir toplum yapısını temel alan muhafazakâr dünya görüşünün ana kolonlarını; gelenek, aile, mülkiyet, reform, devlet ve din gibi öğeler teşkil etmektedir. Bu öğelerin her biri, muhafazakâr düşünce yapısında var olan olgular üzerinde etkilidir.

Çalışmanın temel sorunsalı olan kadın konusu, muhafazakâr düşünce yapısı içinde önemli bir yere sahiptir. Çünkü muhafazakâr siyasi düşüncenin kadını konumlandırdığı yer, onu diğer ideolojilerden farklılaştıran temel unsurlardan biridir. Bunun nedeni kadın için öngörülen statünün, muhafazakâr düşünceyi açıklarken öne sürülen olguların neredeyse tamamından izler taşımasıdır. Kadın ve erkek arasındaki biyolojik farklılık, kadına biçilen rolü doğallaştırmakta ve aile içindeki rol dağılımı bu olgu üzerine inşa edilmektedir. Kadına ve erkeğe biçilen roller ancak toplum içinde var olabilir. Aile ise, kişilerin toplumsallaştığı mekanlardır. Geleneğin taşıyıcısı olan kadının rolü, büyük oranda dinin dinamize ettiği ve ahlakın hâkim olduğu toplumun temeli olarak görülen aile içinde var olur. $\mathrm{Bu}$ bağlamda cinsiyet algısı, din, gelenek, aile, toplum ve ahlak, muhafazakâr düşüncede kadının konumunu anlamak için başvurulan anahtar kavramlardır. Ayrıca bu kavramların çoğunun muhafazakâr düşünce yapısının kadın dışındaki diğer olgularını açıklamada da kullanıldığını belirtmek yerindedir. Bunun diğer bir anlamı, muhafazakâr siyasi düşünce yapısında kadının konumu ile ilgili yapılacak bir tahlilin, aynı zamanda muhafazakâr düşünce yapısının analizi anlamına da geleceğidir.

Muhafazakâr düşünce yapısının öğelerinin kadının toplumsal konumuna bakış açısını ortaya koymayı amaçlayan bu çalışmada, tarihsel ve betimsel araştırma yöntemlerinden yararlanılmıştır. Çalışma üç ana bölüm halinde tasarlanmıştır. Takip eden birinci bölümde, muhafazakâr düşünce kavramsal ve tarihsel yönleri ile ele alınmış; ikinci bölümde ise, muhafazakâr siyasi düşüncenin temel öğeleri üzerinde durulmuştur. Çalışmanın son kısmında, muhafazakâr düşüncenin kadını ele alış biçimi incelenmiştir.

\section{KAVRAMSAL VE TARİHSEL AÇIDAN MUHAFAZAKÂRLIK}

"Felsefi bir düşünce ve siyasal bir tavır olan muhafazakârlık" (Güler, 2012: 117); Latince "conservare" kelimesinden türetilmiş olup, koruma ve muhafaza etme anlamına gelmektedir. Muhafazakârlık, her ne kadar siyasi düşünce bakımından modern döneme ait bir tavır ve hareket olsa da muhafazakârlığın kökenlerinin Aristo’ya kadar dayandığı iddia edilmektedir. Latince "conservator" kelimesi, Ortaçağ toplumlarında yasaları ve belli grupları koruyan anlamında kullanılmıştır. Kavram olarak muhafazakârlığın (conservatuer) Fransız siyasi literatürüne girişi ise, Fransız Devrimi sonrasına denk gelmektedir (Akkaş, 2003: 242). 1815 sonrası dönemde François René de Chateaubriand tarafından genel olarak siyasal yelpazede "să̆" kanadı tarif etmek amaciyla kullanılan, Almanya'da 1830'larda ortaya çıkan (Güler, 2012: 119), İngiltere'de ise, The Quarterly Review editörü J. W. Croker 
tarafindan 1830'da İngilizceye tercüme edilen muhafazakârlık; ilk muhafazakâr hükümeti kuran Sir Robert Peel'in partisinin temel dayanakları olarak, 1834 Tamworth Manifestosu'nda yer almıştır. Muhafazakârlık, aynı yıllarda Calhoun, Webster ve Brownson'un kullanımlarıyla Amerikan siyasi literatürüne girmiştir. Günümüzde muhafazakâr siyasi düşüncenin temel referansı olarak kabul edilen ve İngiliz liberal Whig Partisi’nde milletvekilliği yapmış olan Edmund Burke (1729-1794), muhafazakârlık (conservator) yerine, koruma (preservation) terimini kullanmayı yeğlemiştir. Bu tarihsel sürece dayanılarak muhafazakârlık teriminin siyasi literatürde kullanımının yaklaşık iki yüzyıl öncesine kadar uzandığı söylenebilir (Akkaş, 2003: 242).

Kökenini ne kadar eskiye dayanırsa dayansın muhafazakârlığın gelişip şekillenmesinde Aydınlanma Hareketi, Sanayi Devrimi ve Fransız Devrimi etkili olmuştur (Yayla, 2004: 157). Aydınlanma Hareketi, bu öğelerin başında gelmektedir. Aydınlanma Hareketi'nin temel felsefesi, rasyonalizme (akılcılık) dayanmaktadır. Rasyonalizm, insan davranışını yönlendiren en mutemet rehberin gelenek yerine aklın ve muhakemenin olduğunu savunmaktadır (Ergil, 1986a: 111). Muhafazakârlık, Aydınlanmanın iyimser yönünü ifade eden mükemmelleşebilirlik anlayışının zıttı bir anlayış ile insan doğası ve aklı konusunda menfi bir felsefi zeminden yola çıkar. Aydınlanma, akıl sayesinde insanın kendisini ve yaşadığı toplumu mükemmel kılabileceği hususunda şüphe duymamış ve onun ferdi, sosyal ve politik ereklerini sınırlayacak başka herhangi bir değer tanımamıştır. Hâlbuki akıl çağı ve onun akabinde gelen çağ(lar)ın insanlık tarihinin önceki dönemleriyle mukayese edilemeyecek bir yıkıma sahne olması, insan aklına atfedilen rolün muhafazakâr eleştirisine yönelik kötümser bir felsefi bakışı, Aydınlanma iyimserliğinin karşısına dikmiştir. Muhafazakârlığın bu kötümser tutumu, insanın doğasından gelen sınırlı bir varlık oluşuna, aklın zayıflığına ve dünyayı daha iyi kılamayacağına dair mükemmeliyetçiliğin olanaksızlığı düşüncesinden kaynaklanmaktadır. Buna göre aklın belirli bir kavrayış gücü vardır; akıl, belirli bir düzen içerisinde yer alarak diğer tüm beşeri değerlerin üstünde yer alan ve dolayısıyla onlardan bağımsız bir şekilde kendisine başvurulmasını haklı kılacak yüce ve yanılmaz gücü temsil etmemektedir (Özipek, 2011: 63-64).

Muhafazakâr bakış, toplumun yaşamışları, yaşayanları ve yaşayacakları arasında bir ortaklık olduğu fikrine dayanır. Muhafazakârlara göre toplum, somut bir organizmadır ve toplumun sözleşmeye dayandığı öne sürülemez (Mollaer, 2008: 51). Doğal düzen, ahlaki bir düzen olarak algılanır (Ergil, 1986a: 120). Aydınlanma'nın "soyut haklar ve sözleşmeye dayalı toplum” anlayışını şiddetle eleştiren muhafazakârlar, düşüncelerinin temellerinin Ortaçağın inanç ve değerlerinde bulan, din, aile ve lonca gibi geleneksel kurumlara dayanan "kadim toplumsal düzen"i savunur (Karatepe, 2011: 51-52).

Toplumsal düzenin bozulmaması, onun istikrarının korunması konusunda hassasiyeti ile beliren muhafazakâr düşüncenin doğuşuna etki eden diğer bir faktör, Sanayi Devrimi'dir. Sanayi Devrimi'nin akabinde oluşan yeni sosyolojik yapı, muhafazakârların önem verdiği aile, cemaat, akrabalık ve komşuluk ilişkilerinde önemli ölçüde tahribata yol açmıştır. Tonnies’in vurguladığı "gemeinschaft"1n (topluluğun) "gesellschaft”a (topluma) dönüşümüyle, başka bir ifadeyle bel kemiğine benzeyen düzenlilik ve uyumdaki geleneksel toplumu ayakta tutan temel taşların bozulması ile birlikte 
yabancılaşma ve çözülmeyi ifade eden toplumsal kaosa neden olan sosyolojik bir yapı oluşmaktaydı. Sanayi Devrimi'yle birlikte gelişen yeni toplumun odak noktasını, cemaat yapılarının yönlendirdiği köylerden ziyade kentler teşkil etmeye başlamıştır. Kentteki nüfus artışından dolayı çözülen toplum yapısı yerini güçsüz ve parçalanmış bir yapıya bırakarak geleneksel tesanüt, bağlılık gibi muhafazakâr değerleri tabiatıyla tasfiye etme sürecine girmiştir (Çaha, 2007: 103-104).

Fransız Devrimi ise, muhafazakârlı̆̆ın gelişiminde adeta bir lokomotif görevi görmüştür. Devrim, kısa sürede dünyanın dört bir yanına yaydığı düşünce ve ilkelerle birlikte yalnızca Fransa'da yerleşik düzeni yıkmakla kalmamış, beraberinde pek çok ülkede boy gösteren devrimlere ve yenileşme hareketlerine de öncülük yapmıştır (Ergil, 1986a: 111). Devrim, Fransa'da “özgürlük, eşitlik ve kardeşlik" idealleri etrafında gerçekleşmiştir. Batı dünyasında heyecan yaratan Devrimin hemen ardından Burke, kendisini sonradan "muhafazakârlığın kurucusu veya en büyük düşünürü” (Jones, 2017: 178) olarak tanımlanmasını sağlayacak "Reflections on The Revolution in France"i yazmıştır. Burke (1951: 75-76) kitabında eski düşünceler ve yaşam kurallarının ortadan kaldırılması halinde yaşanacak kaybın tahmin edilemeyeceğini belirtmiş ve artık kendilerine rehber olacak bir pusulanın olmayacağını ve ne yönde bir yol izleyeceklerinin belirsiz olduğunu ifade etmiştir. Fransız Devrimi’nin meydana getirdiği iyimserlik rüzgârlarının tüm Avrupa'ya egemen olduğu bir ortamda Devrimin sert bir şekilde eleştirildiği bu kitap, büyük bir tepkiyle karşılanmış ve başta Thomas Paine olmak üzere, birçok yazar tarafından eleştirilmiştir (Özipek, 2011: 69). Ancak Devrimin akabinde 1793'te gerçekleşen halk ayaklanmasıyla iktidara geçen Jakobenler döneminde başlayan, herkesin daha fazla kana ve teröre tanıklık ettiği Terör Döneminde yaşananlar (Davis, 2010: 235), Burke’u ve onun eleştirilerini çürütmeye kalkışmak için uğraşan radikallerin bile umutlarını yıkmıştır. Burke ve Paine arasında yaşanan tartışma, siyasi bir ayrılığın dışında felsefi bir çatışmanın açıklamasıydı. Burke, "aslında bir ilke ile savaşıyoruz”u söylerken bile gerçek nedenin Jakobenleri ortaya çıkaran ve sorumluları arasında Rousseau'nun da dışında tutulmadığı Aydınlanma ilkeleri olduğunu ifade etmiş oluyordu (Özipek, 2011: 69).

Fransız Devrimi her şeyi baştan yaratma çabası ile tarihsel zinciri koparmak ve yeni temeller atmak çabası içinde olmuştur. Geçmişle bağını korumak isteyen Burke'un muhafazakâr düşünce yapısı bu noktadan hareketle şekillenmektedir. Geçmişten gelen tarihi mirasın ne pahasına olursa olsun korunması ve güvence altına alınması; geçmişle bizler arasındaki bağı sağlamlaştırdığından cemaat yaşamı için vazgeçilmez olan bir unsurdur. Tarihsel süreç içinde kazanılmış tecrübeler bir araya getirilerek zenginlik yaratılabilir, yaratılan bu zenginlik, zor ve karmaşık olan hayatın yapısına ve unsurlarına cevap vermek konusunda sınırlı olan akıl üzerinde kurulamaz; bundan dolayı insan aklının doğayı, geleneklerin derinliğini, ağırlığını ve bilgeliğini anlama için yeterli olmadığı düşünülmektedir (Ceylan, 2007: 39).

Yukarda sayılan üç olgu, yeni bir toplumsal düzen meydana getirme çabası içeresinde olan muhafazakâr anlayış tarafından kabul görmemektedir. Çünkü "muhafazakârlığın genel olarak insanı geçmişten gelen ve süreklilik arz eden kurulu toplumsal düzenin parçası olarak ele alma eğilimi içinde olduğu rahatlıkla görülebilir” (Aytaç, 2015: 116). Beneton (2011: 50)'a göre muhafazakârlık 
canlandırdığı gelenekselliğin hizmetinde olan, karşı devrimci anın ürünü olarak tanımlamaktadır. Özellikle Aydınlanma Hareketi ve Fransız Devrimi neticesinde siyasal ve sosyo-ekonomik hayatta beliren hızlı değişim ve dönüşümlerden olumsuz yönde etkilenen toplumsal kesimlerin kendilerini korunaklı hissettiği, kendi değer ve mantalitesine yakın gördükleri eski düzene duydukları özlemi, yaşanan değişim ve dönüşüme duydukları tepkiyi, alışı oldukları eski düzeni geri getirme ya da eski düzene özgü kurumların korunmasına olanak sağlayacak usul ve tedrici bir değişime dönük isteklerini yansitır (Tok, 2015:232).

Liberalizm ve sosyalizm gibi bir ideoloji olarak tanımlanan muhafazakârlık, düşüncelerini soyut akla ve soyut düşüncelere dayandırmaktan kaçınmaktadır. Çünkü kendisini gelenek ve tecrübeye dayandıran muhafazakâr düşüncede insanların sınırlı akıl kapasitesine sahip oldukları anlayışı hâkimdir (Akınc1, 2012: 52-53). Muhafazakâr siyaset, daima belirli somut koşullara bağlı olmuştur ve muhafazakâr siyasetin dönemin şartlarına göre farklılık gösteren, pratik ve pragmatik bir yanı bulunmaktadır. Muhafazakâr siyaset, güçlünün haklılı̆̆ına, sonucun takip edilen yolu haklı gösterdiğine dayanan bir güç ideolojisine haizdir. Dünyayı üzerinde düşünmeden, otantik biçimde algılayan eski düşünce biçimlerine karşı muhafazakârlığın bilinçli ve "kendi hakkında düşünür" çabası, muhafazakârlığın bir ideoloji olarak inşasına işaret etmektedir (Güler, 2012: 118-119).

Muhafazakârlı̆̆ın sağ kanatta bir ideoloji olduğu yorumlansa da muhafazakârlık, gerçeği tek boyuta indirgediklerini düşündükleri ideolojilere soğuk bakmaktadır. Oysa muhafazakârlığa göre gerçek hiçbir ideolojinin tekelinde olmayacak kadar çok boyutludur. Ayrıca her doktrinin değişmez ilkelere sahip olduğu düşüncesi, muhafazakarlığın pragmatizm aracılığıyla kendini değişmez ilkelere kapatmasına neden olmaktadır. İdeolojiler düzeni ve ahengi bozarak değişime zorlarken; muhafazakârlık değişime şüphe ile yaklaşmakta ve ihtiyaç oranında değişimi kendiliğinden, fonksiyonalist bir anlayışla mümkün görmektedir (Safi, 2005: 14).

Muhafazakâr siyaset; tek bir düşünce yapısı içinde toplumu tesis etmek, tek bir amaca tek bir otorite altında erişmek için örgütlü bir siyasal düzen kurma iddiasındaki ideolojilerden tamamen ayrılır. Muhafazakâr siyaset; resmi bir ideolojiye dayanan devlet aygıtını, merkeziyetçi yanı baskın güçlü bir bürokrasiyi, toplumu denetleyen iletişim ve baskı araçları ile toplumun bir bütün olarak organizmik bir yapı içerisinde ideolojik hegemonya altında seferber edilmesi gibi argümanlarla bizatihi oluşmuş sosyal sözleşmeleri tek taraflı fesheden evren, doğa, bireysel ve sosyal düzenlemeleri benimsemez. Ayrıca asırlar boyunca kazanılan tecrübe ve faydalardan yararlanılarak oluşturulan yasaları; süreksiz, tinsel, izafi ve beșeri ilkelerin kaprislerine feda edilemeyecek kadar değerli görmektedir. Bu nedenle muhafazakâr siyaset, her türlü toplum mühendisliği projelerini tahripkâr bulur, bu meyanda ideolojileri de kaçınılmaz olarak totaliter ilan eder (Çetin, 2004: 111).

Dolayısıyla, bütün ideolojilere mesafeli yaklaşan ve kendisini de bir ideoloji olarak addetmekten imtina eden muhafazakâr düşünce ve hareket (Yanardağ, 2004: 26), ideolojik inaklar sisteminden ziyade bir sezgiler/hisler manzumesine dayanmaktadır. Bunlara inanan ve bu şekilde düşünen bir kişiye de muhafazakâr denilebilir (Kirk, 2008: 243). Eğer bir kişi muhafazakâr ise, belli 
biçimlerde düşünme ve davranma eğiliminde olmalı, birtakım davranışları ve beşeri durumların şartlarını diğerlerine tercih etmek, belli tür seçimleri yapmaya eğilim gösterebilmektedir (Oakeshott, 2004: 55). Muhafazakârlığın özü, tarihsel evrim sürecinin semeresi olarak görülen mevcut kurumsal yapıyı/düzeni, birtakım radikal akımların tehditlerine karşı belirli argümanlardan istifade ederek savunmak ve meşrulaştırmaktır. Bu kapsamda özle değil, daha çok usulle ilişkili olarak algılanan muhafazakârlığın, sabit bir kurumsal düzeni bulunmamaktadır. Bu yüzden farklı kurumsal düzenlerle bir arada görülebilir (Duman, 2010:490).

Ergil (1989'dan aktaran; Safi, 2005: 11-12), muhafazakârlığın "her siyasal rejimde görülebilir" nitelikte olan "genel bir tutum ve tavır alış" olduğunu ifade etmektedir. Bu açıdan muhafazakârlık, mevcut durumu (status quo) korumayı amaçlayan her türlü düşünce ve eylemi niteleyebilecektir. Buna göre de, "değişmenin değil, varılmış olan noktanın 'mümkün olanın' en iyisi olduğunu savunan, daha öteye geçmenin sakıncalı olduğunu vurgulayan ve bunu düşünsel ya da eylemsel olarak engelleyen her siyasal görüş/iktidar, muhafazakâr olmaktadır”.

Gündelik hayatta balık tutmanın dahi muhafazakâr olduğunu söyleyen Micheal Oakeshott'a göre "muhafazakâr olmak, bildik olanı bilinmeyene, gerçeği muammaya, fiili olanı mümkün olana, sınırlı olanı sınırsız olana, yakındakini uzağa, yeterliyi bolluğa, uygun olanı mükemmele, şimdiki sevinci ütopyacı mutluluğa tercih etmektir" (Güngörmez, 2004: 12).

\section{MUHAFAZAKÂR SIYYASİ DÜŞÜNCENIN ÖĞELERİ}

\subsection{Gelenek}

Toplumun düzensiz ve otoritesiz varlığını sürdüremeyeceği görüşünü benimseyen muhafazakâr düşünceye göre, toplum varlığının sürdürülmesi, düzen ve otoritenin sağlanmasında başat olan değerlerden biri geleneklerdir (Türe, 2005: 43). Modern zamanlarda beliren ve modernizme karşı çıkan entelektüel (ve siyasal) bir hareket olarak muhafazakârlık, Avrupa uluslarının geleneksel, siyasal ve toplumsal düzenini savunmak için oluşup, temelde anti modern bir niteliğe sahiptir. Bundan dolayı, saf muhafazakârlık bir gelenekçilik olarak görülmektedir (Beneton, 2011: 10-11). Muhafazakâr düşüncenin özeğinde bulunan "muhafaza etme arzusu"; yerleşik gelenek ve göreneklere, geleneğin haiz olduğu erdemlerle zamanla yerleşe gelmiş müesseselere duyulan itibarla yakından ilişkilidir (Heywood, $2011 \mathrm{~b}$ : 76). Toplumların ortak mirası olarak görülen unsurları oluşturmasından dolayı gelenekler, toplumların sürekliliğinin ve toplumsal meşruiyetin kaynağı olarak kabul edilirler (Yılmaz, 2005: 40). Ayrıca insanların birey olarak sınırlı düzeydeki aklıyla her şeyi idrak etmesinin olanaksızlığına ilişkin inanç da muhafazakârların geleneğe güven duymalarının kökeninde yatmaktadır (Özipek, 2011: 105). Genel olarak gelenekçiliğe yatkın kişiler olan muhafazakârlara göre, bir geleneğin uzun süreli olması da onun en doğru bilgi olarak algılanmasına yol açar (Muller, 2000: 56).

Her ne kadar muhafazakâr düşünce, köklü gelenekler etrafinda biçimlense de bu, muhafazakârlıkta tüm geleneklerin korunacağı anlamına gelmemektedir. Scrutan'ın da belirttiği gibi, birbirine rakip gelenekler vardır ve her gelenek muhafazakârlık açısından aynı ölçüde korunmaya layık değildir. İşkence, suç ve devrim geleneklerini ise, korunmaya layık olmayan gelenekler olarak 
nitelendirmektedir. Scrutan, muhafazakârlığın bir geleneği desteklemesi için tatmin edici üç bağımsız kritere bağlı olduğunu belirtmektedir. Bu bağlamda "ilk kriter, geleneğin, şanlı bir tarihin verdiği değere sahip olması; ikinci kriter, o geleneğe bağlılarının sadakatini içinde barındırıyor olması; üçüncü kriter ise, kaynaklandığı fiilden daha uzun ömürlü olması ve ona anlam vermesidir" (Tannsjç, 1990'dan aktaran; Özipek, 2011: 110). Gelenek, muhafazakâr ideolojinin ontolojik kusuru telafi etmek için kullandığı bir araç olarak nitelendirilip, bu bağlamda insanın giderilemez eksikliğinin sadece atalar tarafından tecrübe edilmiş bilgilerin uygulanmasıyla alt edilebileceği fikrini barındırır (Mollaer, 2008: 47).

2.2. Aile

Zamana karşı koyabilmiş değer, uygulama ve kurumları, özelde de bir kuşaktan diğerine nakledilebilenleri kapsayan geleneklerin ve kurumların tarih testini başarıyla geçmelerinden dolayı hassasiyetle korunması gerektiği (Heywood, 2011a: 86) vurgusunun yapıldığı muhafazakâr siyasal düşüncede aile; bireyin kişilik kazanmasında ve kimlik edinmesinde üstlendiği roller kadar, gelenekleri üreten ve nakleden bir ortam sunması bakımından da oldukça önemlidir (Şeyhanlıoğlu, 2011: 34). Toplumu kombine eden birçok değerin yaratıldığı ve tahkim edildiği, sosyal dayanışmanın sağlandığı, bireye temel eğitimin verildiği aile; muhafazakâr siyasi düşüncede hem toplumu teşkil eden temel bir birim, hem de geleneksel ahlakın koruyucusu olarak addedilen sosyal bir müessesedir. Çünkü aile toplumu birleştiren bağların bir bölümünün türetildiği ve pekiştirildiği bir sosyal atmosferi yaratır. Aile toplumun bölünmesini önlediği gibi, toplumda sağladığı yardımlaşma ve dayanışma misyonuyla adeta bir vakıf, bireye verdiği temel eğitimle de bir eğitim kurumu işlevi görmektedir. Bireylerin aidiyet ve mensubiyet hislerini kuvvetlendiren aile, aynı zamanda onların kendilerini mutlu hissettikleri nadir yerlerden birini de teşkil etmektedir. Bu yüzden ailenin elzem bazı toplumsal işlevleri bulunmaktadır (Vural, 2003: 38).

Aile, muhafazakârlığın kendisinden hareketle bir ideoloji olarak oluşturulduğu, minimal ontolojik varlık olarak da tanımlanabilir. İster Hıristiyanlıktan gelen ilk günah öğretisinde olsun, isterse seküler nedenlerle "kusurlu sayılan insan"ın içinde en ideal şekilde var olabileceği ilk müessese olsun aile, bireyin birçok ihtiyacının tatminine ve eksiğinin giderilmesine olanak sağlayan yegâne bir birliktir. Bu birlik içinde bireyin eksiklikleri telafi edildiği gibi, maddi ve fizyolojik ihtiyaçları meşru çerçevede tatmin edilmekte; sevgi ve bağl1lık hisleri pekiştirilmektedir. Bu bakımdan "kusurlu sayılan insan"ın iyi ve kötü arasında tercihte bulunabilmesinin, ruhsal ve bedensel ihtiyaçlarını meşru yollardan karşılayabilmesinin ailenin "kurumsal rehberliği” yoluyla mümkün olduğu söylenebilir (Özipek, 2011: 106).

\subsection{Mülkiyet}

Muhafazakârlı̆̆ın aile vurgusunun yanında dayandığı en büyük ortak paydalardan biri de kuşkusuz mülkiyet anlayışıdır. Mülkiyet ve otoritenin toplumsal düzenin temelini oluşturduğu vurgusunun yapıldığı muhafazakârlığa göre, devletin ve düzenin korunması ve süreklilik arz etmesi mülkiyet ve otoriteyle olanaklı olup, otorite ve mülkiyet özgürlügün de temelini teşkil etmektedir. Mülk 
edinme ve koruma hakkının iyi bir toplum tanımının ilk koşulu olarak kabul edildiği muhafazakârlıkta, mülkiyetin bir yandan toplumun ana birimi olan ailenin temelini oluşturduğu, diğer yandan da bireye toplumda belirli bir konum kazandırdığı anlayışı hâkimdir (Türe, 2005: 45).

Aslında muhafazakârların aileye saygısı da aileyle mülkiyet arasındaki yakınlıktan kaynaklanmaktadır. Muhafazakâr mülkiyet teorisinde mülkiyet, bireyin gereksinimlerinin karşılamasında eşsiz konuma sahip olan ve ondan bağımsız düşünülemeyen tamamlayıcı bir parçası olarak addedilir. Mülkiyet, medeniyette insanın insaniyetinin ve onun bütün doğa üzerindeki üstünlüğünün nişanesi olarak kabul edilir. Romalı iddiaya göre bir fert çok eski dönemlerin birinde bir toprak parçasını alıp onu "benim" diye ilan etmedikçe, insanın toprak üzerindeki ve onun üzerinde bulunan her şeyin üzerindeki egemenliğini iddia etmesi ve böylece bunun medeniyetin gelişmesinde ilk adım olması olanaksızdı. Muhafazakâr mülkiyet düşüncesinin ve bu düşüncenin karakteristiğine işlemiş olan Romal1-feodal unsurun bütün özü elbette ki, mülkiyeti muhafaza yasalarında ve örflerde "en büyük oğul önceliği” olarak görülmektedir. Her ikisi de mülkiyetin aile karakterini korumak ve onu bireysel mülkiyetin müphem ve devredilebilen sahipliğinden korumak amacıyla tasarlanmıştır (Nisbet, 2011: 9091). "Mülkiyet bir hak olduğu kadar sorumluluktur" diyen muhafazakâr klişe, bu durumu çok latif bir şekilde ifade etmektedir. "Mülkiyet hakkının kişinin kendi tekelindekiyle dilediğini yapmada namütenahi bir özgürlüğe haiz olmadığı” anlayışının benimsendiği muhafazakâr düşüncede, mülkiyet hakkı toplumun ihtiyaçlarıyla sınırlandırılmıştır. Böylece arazi ve mülk sahipleri bir geleneğin (kültürün) taşıyıcıları olarak anlaşılır ve onlara bu geleneği korumada belli görevler atfedilir. Muhafazakâr düşüncede mülkiyetin görevleri net bir şekilde tanımlanmamaktadır. Bununla birlikte hayır hizmetleri yapma sorumluluğu, kamu hizmetlerini ve belli çıkar grupları adına olmaktan ziyade kamu yararına siyaset yapma sanatını içermektedir (Barry, 1989: 102-103).

\subsection{Reform}

Anti-ütopik olan Muhafazakâr düşüncenin siyasi yaklaşımları pragmatiktir. Muhafazakârlar, çeşitli siyasi önerileri değerlendirirken tarihi ve ampirik şartlarının önemini vurgular. Bu nedenle devrimlerin, toplumsal düzeni altüst edip, geleneksel otorite, meslek ve sınıf yapılarını yok ettiği düşüncesi ile insan ve toplumun oluşumunda devrim stratejisi yerine çok ağır yapılan reformları tercih ederler. Reformların her şeyden önce mevcut durumu korumak için olması gerektiğine inanırlar (Vural, 2003: 15). Genel itibariyle tepkiye dayalı negatif bir doktrin şeklinde beliren muhafazakârlı̆̆ın neye karşı olduğu belli olmadığı gibi, taraf olduğu hususlar da açık değildir. Bu düşüncenin E. Burke’un yanında Maistre ve Bonald gibi düşünürlerin eserleriyle şekillenmiş ve teorik olmaktan ziyade siyasi pragmatizme yönelik olduğu söylenebilir. Soyut fikirlere ve doktriner düşünceye karşı olan ana eğilimine rağmen muhafazakârlık basit bir pragmatizm veya oportünizm de değildir. Bireye ve topluma yönelik bir dizi siyasi inanca dayanan muhafazakârlık, değişime tamamen karşı çıkmamanın yanı sıra, değişime karşı pragmatik bir tavır içindedir (Yılmaz, 2001: 92-93). 


\subsection{Birey ve Düzen}

Evrene ve evrende insanın yerine ilişkin belirli bir bakış açısına sahip olan muhafazakâr düşüncede, her şeyin merkezini Tanrı teşkil etmektedir. Bütün varoluşun kaynağı ve ölçüsü olarak Tanrıyı gören muhafazakâr düşüncede, insan doğası kozmolojik düzenin sabit bir parçasından ibarettir. İnsanın doğa yasalarına tabiiyeti de onu tabiaten yetersiz kılmaktadır. İnsanın kendi doğasının ona siyasal etkinliklerde ve hükümetlerin onun adına yapabileceklerine sınırlar getirdiği inancının hâkim olduğu muhafazakâr düşüncede, insan temelde kusurlu ve muhakeme yeteneği sınırlı bir varlık olarak addedilir. İhtiras ve dürtülerin egemen olduğu yaratıklar durumunda olan insanın, suç ve kabahatlere meyilli bir doğaya sahip olduğuna inanılır (Ergil, 1986b: 275-276). Bu bağlamda isyankârlık yapan, otoriteye karşı düşmanlık besleyen, sözleşme ve geleneklere bağlı kalmayı reddeden birey, muhafazakâr kesim tarafından zararlı görülmektedir (Letwin, 2012: 5). Ayrıca ahlaki yönden bozuk olan bireyler; çıkarcı, haris ve iktidar hırsıyla lekelenmiştir. Bu yüzden düzensizliğin ve suçun köklerinin, toplumdan ziyade beşeri bireye uzandığı savı ileri sürülmektedir (Heywood, 2011b: 76).

Muhafazakârların, toplumdaki bireyler üzerinde otoriter denetimlerden yana olması, neden toplumdaki “yasa ve düzen” savunucuları olması gerektiğini açıklar. Bununla birlikte muhafazakârlar, polisin güçlü, yasaların sert ve cezaevlerinin de rahatsız edici olmadığı sürece, insanları caydıramayacaklarını düşünürler (Baradat, 2012: 35). Bu yüzden muhafazakârlar, merkezi bir güç ve otorite sistemi olmaksızın istikrarlı bir toplumun söz konusu olamayacağı düşüncesini savunmaktadır. Bu bakımdan devlete itaat ve yasalara riayet, muhafazakâr düşüncenin temel prensiplerinden birini teşkil eder (Aktan, 2007). Ayrıca muhafazakâr siyasi düşünce, mevcut toplumsal yapıda kargaşa yaratacak, 'düzen' ve bu düzen içinde oluşan 'anlam'1 zedeleyecek siyasal tasarruflara karşı bir duruş sergilemektedir (Duman, 2010: 491).

Muhafazakârların ‘düzen'e yaptığı bu vurgu, ünlü Amerikan siyaset teorisyeni Russell Kirk’in anayasa tahayyülünde de görülmektedir. Kirk’e göre iyi bir anayasanın ilk ilkesi, uzunca bir ara birlikte yaşamış bir halkın üzerinde ortak deneyimine dayanmasıdır. "Düzen, adalet ve özgürlüğü" koruyabilen anayasalar bu açıdan bakıldığında üretilmemiş; insanların alışkanlıklarından ve sosyal ilişkilerinden gelişmiştir. Kirk'in anayasal ilkeler arasında yer verdiği ikinci ilke, insanoğlunun dini yapısı, anayasanın ve kamu düzeninin standartlarını arttırmak için gerekliliği ve kendilerinden ya da devletten daha güçlü olan iktidardakileri etkilemesidir. Kirk'in üçüncü anayasal ilkesi ise, kişiselliği ve yetenekle, gücünü, konumunu ve sorumluluğunu toplumdan almış kişileri birleştiren 'doğal aristokrasiye' toplumun olan ihtiyacıdır. Son olarak Kirk, iyi bir anayasanın özgürlük ve düzen iddiası arasındaki dengeyi koruyacağı ilkesini belirtir. Anayasanın bireylerin haklarının olması gerektiği gibi koruması için, anarşiyle sonuçlanmayacak şekilde toplum düzenini de koruması gerekmektedir (Frohnen, 2004: 461-462).

Ergil'e göre (1986a: 123), muhafazakâr düşüncede "özgürlükler yasa ile tescil edilmiş olduğundan, yasalara uyan insan, özgürlüğ̈̈ hak etmiştir.” Özgürlükler bireylerin var olan yasalara uyma düzeyi ile ölçülür. Bu durum muhafazakâr düşüncede, özgürlük kavramının "insanın doğası" türünde spekülatif bir kavramdan kaynaklanan, her derde deva bir "reçete" olmadığını yansıtır. Örneğin: 
Bir İngiliz için özgürlük, 'habeas corpus ilkeleri' ile gerçeklik kazanamamaktadır. Ancak bu ilkeler demetinin varlık kazanması, özgürlüklerin yasaya dönüştürülmüş olması ile mümkündür. Diğer bir ifadeyle, özgürlükler varlıklarını "dışsal sınırlamaların” yokluğunda elde etmektedir. Sınırlamaların kaynağını, genellikle baskıcı bir güç teşkil eder. Bu nedenle her türlü sosyal gücün kapsamlı ve çok özekli tutulması, Batı'nın muhafazakâr geleneğinde büyük öneme haizdir.

Muhafazakâr yöntem, insanın sınırları ve hareket alanı belirlenmiş bir evrende toplumun ve tarihin bir ürünü olarak var olduğuna; ona atfedilen rollerin ve mücadele alanlarının da ancak bu olgularca saptanan aile, kültür, ananeler ve din gibi argümanlardan kaynaklanacağına inanır. İnsanları kendilerini oluşturan bu bütünlüklü yapının haricindeki parçalarla (parti, ideoloji, elit, öbek, hizip) tanımlamak ve anlamlandırmak, insanın kendini gerçekleştirmesine engel olmaktır. İnsan kendisini en iyi, dâhilinde tanımlı bulunduğu düzenin kural dünyasına uyarak bulabilir. Bunun haricindeki tüm ayrımlar, tarihsel ve sosyal hakikatlerden uzak, soyut ve eğreti değerlerdir. Kalıcı olana adapte olmak yerine, eğreti olan için didişmek anlamsızdır (Çetin, 2004: 104).

\subsection{Din}

Muhafazakâr ideolojide, yenilik olarak insanlara verilen her şeyin aslında insanları her bakımdan yozlaştırdığı, insanlığın değer yargılarını, geleneklerini, dini inançlarını adeta yerle bir ettiği savı benimsenmiştir. Muhafazakâr ideolojide ileri sürülen bu tezin savunulmasında, özellikle "aile ve Kilise gibi kutsal, sosyal işlevi vazgeçilmez olan kurumların parçalanması ve değersizleştirilmesinin insanlık için bir felaket olacağı kaygısı" çok başvurulan bir sosyolojik gerekçedir (Tekin, 2004: 86).

Muhafazakâr mekânın kozmik bir evren algılaması, tepesinde Tanrı olan dikey (hiyerarşik) bir örgütlenme üzerine kuruludur. Kozmolojik bir yapıda olan bu düzenin birbirine bağlı ve bağımlı yapı taşları; Tanrı, evren, doğa, toplum ve insandır. Bu düzen, hiçbir parçanın diğerlerinden ayrı ve özel olmadığı organizmik bir bütünlüğü temsil eder (Çetin, 2004: 89). Birey-toplum-devlet birliğinin, bütünlüğünün ve kaynaşmasının yollarını arayan muhafazakârlık ise, tüm bu ayrımların üzerinde ve dışında siyasal ilişkileri yöneten-yönetilen ayrımına dayandırır (Çetin, 2004: 91). Toplumu bir arada tutan değerlerin vazgeçilmez önemi, muhafazakârlı̆̆ın eskisinin de yenisinin de dini ve seküler olanının da üzerinde uzlaştıkları bir konudur. Dinin bireysel ve toplumsal bakımdan önemini de sıkça vurgulayan muhafazakârlar, dini sadece bireysel bir inanç olarak değil, aynı zamanda toplumsal işlevleri olan bir kurum olarak da değerli görürler. Hiçbir toplumun, cemaatin veya grubun dinden bağımsız olarak var olamayacağı düşüncesi bu siyaset felsefesine aittir. Din otoritesi, sembolleri ve kurumları vasıtasıla toplumun birlikteliğini sağlamaya ve korumaya katkıda bulunmanın yanı sıra, manevi bir bağ olarak toplumda birleştirici bir işlev görür. Dini istikrarlı bir toplumun sosyolojik gereği olarak gören geleneksel muhafazakârlık, aynı zamanda doğal hukukun ve siyasi ahlakın kaynağı olarak da görür (Vural, 2003: 122-123).

Toplumsal düzende önemli yer teşkil eden din, muhafazakâr düşünce tarafindan oldukça önemsenmektedir. Dini toplumun çimentosu olarak gören muhafazakârlık, bireyler arası doğal eşitsizlikleri düzenleyici rol üstlendiği, toplumsal istikrara ve otoriteye katkıda bulunduğu gerekçesiyle 
dinin mutlaka var olması gerektiğini savunmaktadır (Şeyhanlığlu, 2011: 39). Başka bir ifadeyle, dindar olmaya veya geleneksel dini değerlerin saptadığı bir tutum takınmayı ifade eden bir tavra dönüşen muhafazakârlıkta, siyasi bir ideoloji olarak dine yapılan ısrarlı vurgunun yanında, devrime karşı ihtiyatlı bir karşı oluş, tutum ve pratiğin varlığı söz konusudur. Bu özellikleri nedeniyle muhafazakârlığın “tutuculuk", "dincilik" ve "gericilik”le karıştırılan bir yönü de bulunmaktadır (Akkır, 2006: 7).

\section{MUHAFAZAKÂR DÜŞÜNCEDE KADININ TOPLUMSAL KONUMU}

Bir ideoloji, düşünce sistemi ve hatta yaşam felsefesi olan muhafazakâr düşünce, Fransız Devrimi'nin sonuçlarına ve toplumsal hayatta aklı ve bilimi esas olarak kabul eden düşünceye karş1 ortaya çıkmış bir akımdır. 20. asra damgasını vuran bu akım, toplumsal duyarlılığın ve bireysel sorumluluğun gelişmesinde önemli roller üstlenen bir görünümde belirir. Ana tema olarak tecrübeye dayanan, tarihsel ve toplumsal duruşu önemseyen muhafazakârlık, bu yönleriyle aynı zamanda sosyolojik olan bir gelenektir. Ayrıca muhafazakârlık hayata ilişkin bir teori olarak görülebileceği gibi, olaylara karşı bir tavır olarak da nitelendirilebilir. Muhafazakârlık, kendi içinde tutarlı ve sistemli bir felsefe, politikadır; ancak hepsinden de önemlisi kadim bir gelenektir (Duman, 2012: 43-44).

Muhafazakâr düşüncede kadın ise, başta gelenekler olmak üzere, aile, ahlak ve yerleşe gelmiş toplumsal cinsiyet algısı etrafında şekillenen bir konuma haizdir. Muhafazakâr düşüncede kadının konumunu şekillendiren etmenlerden biri olan ahlak, ideal toplum ülküsünün üzerine bina edildiği ve muhafazakâr düşünürlerin toplumsal olgulara seçici bir anlayışla yaklaşmasıyla meydana getirilen önemli bir zemindir. Bireyin toplum ve diğer bireylere karşı olan davranışlarına nizam veren genel ahlak, muhafazakâr düşüncede esas gücünü muhteviyatından çok işlevinden almaktadır. Başka bir ifadeyle genel ahlakı değerli ve önemli kılan öncelikli öğe içeriğinin doğru ve muvafik olması değil, varlığının elzem görülmesidir. Yalnız ve serbest bırakıldıkları, terbiye ve eğitimden uzak kaldıkları takdirde bireylerin hem kendileri hem de çevreleri için zararlı oldukları, günaha ve yok oluşa meyilli oldukları düşünüldüğünden, genel ahlak ve bu ahlak temelinde teşkil edilmiş toplumsal düzen, insan varoluşunun zorunlu bir gereği olarak sunulur ve kutsanır (Özsel, 2012).

Benimsenen ahlak anlayışında kadın için belirlenen rol, cinsler arasındaki ayrımının doğal sonucu olarak görülmektedir. Muhafazakâr düşünce tarafından toplum içindeki cinsiyet ayrımlarının doğal olduğu görüşüne itilen kadın ve erkek, doğanın onlar için hazırladığı sosyal rolleri üstlenmesi gerektiği anlayışını benimserler. "Biyoloji kaderdir" anlayışından yola çıkan muhafazakârlar, kadını fiziksel ve anatomik yapısıyla toplum içinde ikinci planda olmaya ve evcil bir rol almaya uygun bir varlık olarak kabul etmektedirler (Heywood, 2011a: 253). Bu bağlamda, organik bir toplum yapısını benimseyen muhafazakârlar için eşitlik, yalnızca başlangıç noktası olarak görülmektedir (Baradat, 2012:37). Böyle bir toplumda eşitsizlik, kaçınılmazdır ve bu sadece bireysel farklılıklardan doğan bir nitelik değildir. Bundan dolayı Burke gibi pre-demokratik muhafazakârlar, "doğal aristokrasi” görüşünü oldukça rahat bir şekilde benimseyebilmişlerdir. Vücuttaki beyin, kalp ve karaciğer nasıl farklı işlevler gerçekleştiriyorsa, toplumu oluşturan farklı sınıf ve grupların da kendilerine ait özel birtakım rolleri (önderler ve takipçiler, yöneticiler ve işçiler, işe gidenler ve evde çocuk bakanlar) bulunmaktadır 
(Heywood, 2011a: 92). Kadının konumun değişmezliği ve doğallı̆̆1 konusunda Alman muhafazakârlığın fikir babası ve kaynağı olarak görülen Hegel (Çaha, 2007:106), kadınla erkek arasındaki ilişkiyle hayvanla bitki arasındaki ilişki arasında benzerlik kurarak şu şekilde özetlemiştir: “Aktif olan, sürekli dolaşıp duran hayvandır. Oysa bitki sürekli olarak aynı toprakta sabit olarak bekler. Bitkinin işlevi hayvanı beslemektir. Ancak kendisini ona sunarken de hayvanın gelip kendisini bulmasını ve yemesini bekler. Çünkü aktif ve gezici olan, ayn yerde sabit durmayan hayvandır. Bitkinin temel işlevi hayvanın yaşamasını sağlamak, onun kanında ve damarlarında yer alarak onunla bütünleşmektir. Kadın da aynı şekilde sürekliliği ifade eden aile içinde bitki gibi sabit kalır. Onu arayıp bulan erkeğidir. Kendisini erkeğine sunarak ona tarihsel anlamda lojistik destek sağlar. Kamusal alana da erkeğiyle bütünleşmiş olarak, onun şahsında girer. Başka bir ifadeyle, erkeğinden bağımsız bir hükmü şahsiyet geliş̧tiremediği için kendi başına kamusal alanda yer alma, dolayısıyla tarihin bir objesi olma şansı yoktur" (Çaha, 2010: 40-41).

Diğer taraftan modern dünyadaki muhafazakârların referansını oluşturan David Hume’un (Çaha, 2004: 16) kadına bakış açısı da bu doğrultudadır; “...bir cinsin elde edebileceği en büyük saygl, sadakatten gelir; ve bir kadın, bu konuda zayıflı gösterirse orta malı ve bayağı olur. Şerefini kaybeder ve tüm hakaretleri hak eder. Küçük bir kusur, şerefini yerle bir etmek için yeterli değildir. Bir kadının her şeyden çok açlığını doyurmak için olanakları olur; yoksa alçak gönüllülüğü ve kendine hâkim olmasl, bizi rahatlatmaz ve bir kere yapılan hata, söylemek gerekirse hiçbir zaman tamamen onarılamaz. Bir erkek firsat bulup alçakça bir şey yaparsa, bunun tam tersini yaparak şerefini kurtarabilir. Fakat bir kez iffeti yok olmuş bir kadın, bizlere kendine yeterince hâkim olabileceği yolunda güvence verebilir mi?"

$\mathrm{Bu}$ alıntıya göre erkek, yanlış yaparsa bağışlanır; kadın yanlış yaparsa bağışlanması söz konusu değildir (Kızılkaya, 2005: 97). İnsanlar arasında her zaman için büyük eşitsizliklerin var olduğunu vurgulayarak toplumu bir başka varsayıma dayandırma yoluyla kurma girişiminin "budalalık" olduğunda 1srar eden muhafazakârların (Baradat, 2012: 36) cinsiyet algısı, kadın ve erkeğin aile ve toplum içindeki rollerini belirlemektedir. Bu kapsamda muhafazakârların geleneksel anlayışında, toplumun doğası gereği hiyerarşik olduğu ve sabit, yerleşik sosyal derecelerle nitelendirildiği fikri yatmaktadır (Heywood, 2011a: 92). Kafa ve kol tabirleri erkeğe ve emeğe ait olarak kullanılırken, kadınlar biyolojik yazgılarının bir sonucu olarak yaptıkları üretken işlevlerde emeğini satmakta "özgür” sayılmamaktadır. Ücretli emeğin sosyal maliyetini ve ikili işgücü piyasası aracılığıyla gerçek ücretleri düşürdügü düşünülen kadın bu yönüyle erkekleri de çalışmaya mahkûm eden, dolayısıyla onunla bir bütün olarak düşünülmesi gereken bir unsur şeklinde kabul edilmektedir. Ayrıca, kadına biçilen bu rol, çalışan erkeğin yeniden üretim koşullarını sağlamada muhafazakârlığın disipline edici diğer bir işlevine tekabül etmektedir (Balta, 2012: 2).

Muhafazakâr düşüncede, özgürlük toplumun dışında değil içinde aranmalıdır ve başta gelenek ve din olmak üzere aile ve cemaat ilişkileri bireyi özgür kılan müesseseler olarak görülmektedir. Çünkü insan, sadece toplum içinde kalarak kendini gerçekleştirebilir, gizil güçlerinin farkına varabilir ve 
yeteneklerinin kapasitesini görebilir. Nisbet'in deyişiyle; "toplum, birey için adeta her şeydir". Kural tanımayan bir bireycilik, sadece akılla hareket etmektedir ki, saf aklın insanı doğru yola ulaştırması imkânsızdır. Bundan dolayı birey, kutsal bir şemsiyenin altına girmeli, dinin ve geleneğin gücünden yararlanmalı ve en önemlisi aile kurumuna güvenmelidir. Bu nedenle geleneğin kadim kurumları arasında yer alan aile, muhafazakâr ideolojinin adeta vazgeçilmez kurumlarından birine dönüşmüştür. Toplumsal değerlere ve normlara aşinalığın kazanıldığı ve kişinin toplumsallaşmaya başladığı ilk kurum olan aile, aynı zamanda geleneksel yapının, dini normların, otorite ilişkilerinin ve kolektif iradenin de gerçekleştiği ve bizzat aktif olarak yaşandığı bir kurumdur (Duman, 2012: 44-45).

Muhafazakâr düşüncede, geleneği aktaran ve yeniden üreten bir araç olarak yer alan kadın; ana, eş, bacı ve kız gibi aile kavramı içerisinden türetilen toplumsal rollerle hüviyet kazanmıştır (Kaya, 2014). Kadın, bu hüviyetlerini toplumsal kurumlarda elde etmektedir. Muhafazakâr düşünceye göre birey ve toplum arasında aracılık işlevi gören cemaatler olmaksızın toplum yapısı bozulur, fertler arasında bağlar kopar, atomize olmuş bir yapı ortaya çıkar. Toplumsal birlikteliği sağlayan şey de patriarkal değerlerin taşıyıcısı olarak kadın ve erkeğin birlikteliğine dayanan aile, cemaat ve lonca gibi kurumlardır (Özgün, 2014: 15). Bu nedenle muhafazakârlık, gelenekselin muhafaza edilmesi şeklinde ifade edilse de muhafazakârlaşma süreçlerinin tahlilinde öncelikli olarak aile ve kadının statüsü sinamaya tabi tutulur (Balta, 2012: 1). Muhafazakârlığa göre toplumun en temel birimi olan aile, aynı zamanda toplumsal yapının en eski ve başarılı kurumunu teşkil etmektedir. Aile monarşi gibi tasarlanmakta olup, bu yapıda kral rolünde baba ve uyrukları yer almaktadır (Özgün, 2014: 14). Geleneksel olarak roller ve sorumluluklar, aile içerisinde cinsiyetçi bir anlayışla paylaşılmaktadır. Kadının sorumlulukları; yemek pişirme, bulaşık yıkama, ev temizleme ve çocuk bakmak gibi işlerle sınırlı tutulmaktadır. Muhafazakâr ideolojilerin ev işleri konusunda sıkça vurguladığı "cinsiyete dayalı iş bölümü”nün en önemli sorunlarından birisi kadının emeğinin göz ardı edilmesidir. Öyle ki kadının, evin ve aile fertlerinin düzenini sağlamak adına üstlendiği işler, ekonomik karşı1lı̆ı olmamasından kaynaklı olarak, gerek aile fertleri gerekse toplum tarafindan değerli bulunmamaktadır. Öte yandan kadın uğraşları karşılığında emeklilik, sosyal güvenlik hakları da edinememektedir (Başterzi, 2013: 11).

Erkek evlenmek istediğinde mutlaka kendisiyle ev kurma sorumluluğunu paylaşacak, kadına hasredilen geleneksel rolleri üstlenecek bir kadın bulmak zorundadır (Kirk, 1985'ten aktaran; Dural, 2006: 64). Kadın ve erkek, çift olma durumunda çoluk çocuk meydana getirir. Muhafazakâr bakışta çocuklar bir lütuf ve nimettir. Çocuk yetiştirmek, ailenin doğal işidir. Aile, çocukları sevgi ile büyütmeli ve onlara geleneksel ve ruhsal miraslarını aktarmalıdır. Bu şekilde çocukları toplumsallaştırmalı ve nesilleri birleştirmelidir. Aileler, bu önemli işi yaparak toplumda saygı ve şeref kazanırlar (Winker, 2005: 18-19). Bu nedenle muhafazakârlar kürtaja şiddetle karşıdırlar ve kürtajı "en temel insan hakk1 olan yaşama hakkı"nın ihlali olarak görmektedir. İnsan hayatının annenin hamile kaldığı ilk günden itibaren başladığını ifade eden muhafazakârlar, anne karnındaki bir bebeğin doğum dışı bir sebeple alınmasını da cinayet olarak görmektedir. Masum insan hayatına son vermek olarak görülen kürtaj, açık bir dille "şeytana hizmet etmek" şeklinde yorumlanmaktadır (Köni ve Torun, 2013: 197). 
Muhafazakârlara göre, yetkin olmayan bir varlık olarak insan, konu kendi bedeni bile olsa, sınırsız bir yetkiyi elinde bulundurmamaktadır (Özipek, 2011: 202). Kürtajın tamamen kaldırılması yönünde çaba gösteren muhafazakârlar, öte yandan kürtaja sebebiyet veren şeyleri ortadan kaldırmaya yönelik çalışmalar içerisindedirler. Bu çalışmalar arasında evliliğin teşviki ve kolaylaştırılması, evlilik sonucu doğan çocuklar için ailelere maddi destek sağlanması, evlilik dışı doğum ve on sekiz yaş altı hamileliklerin destek kapsamı dışına alınması, hamilelik bakım ve bilgilendirme merkezlerinin kurulması, kürtaja karşı eğitim gibi şeyler yer almaktadır (Köni ve Torun, 2013: 197).

Muhafazakârlığın ilk evresinden itibaren yoğun patriarkal eğilimler barındırdığını söylemek mümkündür (Dural, 2004: 123). Patriarkal görüş, kadın ve erkekleri, yalnızca biyolojik olarak değil, aynı zamanda gereksinimleri, ehliyetleri ve işlevleri bakımından da farklı görür. Ayrıca bu görüşte Tanrının kadın ve erkekleri toplumsal işlevler açısından da farklı yarattığı anlayışı söz konusudur. Yani, erkekler "doğal olarak" daha güçlü ve akılcıdır, dolayısıyla hükmetmek için yaratılan erkekler, siyasi olanı, devleti temsil etmeye ve yönetmeye daha elverişlidir. Kadınlar ise, "doğal olarak” daha zayıf, akıl ve rasyonel yetenekler açısından daha aşağı, duygusal açıdan ise, dengesizdirler. Bu özelliklerinin onları güvenilmez ve siyasal katılım açısından elverişsiz kılmasından dolayı, siyasal/kamusal alanın dışında kalmaları gerektiği vurgulanır (Berktay, 2009: 26-27).

$\mathrm{Bu}$ yönleriyle muhafazakârlık bir siyaset kuramından ziyade, devrimci kopuşlara karşı duruşu öneren bir tepki ideolojisidir. Modern siyasal hayatta karşı devrimci dönemlerin, isyanların bastırıldığ1 dönemlerin ürünü olan bu ideoloji, "beş parmağın beşi bir olmamalı”, “ayaklar baş olmamalı”, "erkekler kadınlara, kadınlar erkeklere benzememeli” gibi söylemlerin vücut bulmuş halidir. Toplumdaki geleneksel ve yerleşmiş değer yargılarının büyük kesintilere uğramasına karşı çıkmayı temel alan bu ideoloji, hep eski bir toplumsal düzenin nostaljisini taşımış, toplumun doğal, canlı bir organizma olduğunu benimsemiştir (Koç, 2014: 28). Muhafazakâr düşüncede kadının konumunun doğal görünümü kadına biçilen rolü meşru kılan önemli bir zemindir.

Bu noktada Fransız Devrimi'nin sonuçlarını yakından izleyen ve Devrim sonrasında Almanya'da kurulmaya çalışılan demokrasiye karşı çıkan Schopenhauer'un şu ifadesine değinilmesinde yarar vardır: "Çünkü erkeğin aşkl, doyuma ulaştığı andan itibaren yavaş yavaş azalır, neredeyse sahip olduğunun dışındaki bütün kadınlar, onu çeker, canı değişiklik ister. Buna karşıllk, kadının aşkı o andan itibaren (cinsel birleşme) artar. Bu da doğanın amacına, yani türün mümkün olduğunca fazla çoğalması ve devamlılı̆̆ı korunmasına uygun bir sonuçtur. Erkek, ĕger elinin altında yeteri kadar kadın varsa, bir yılda hiç sorunsuz yüz çocuk yapabilir; oysa bir kadın benzer sayıdaki erkekle bile yılda ancak bir çocuk doğurabilir. Erkek, hep başka kadınlar ararken kadın, tam tersine tek bir erkeğe sıkı sıkıya bağlanır. Çünkü doğa, düşünmesine firsat vermeden doğacak çocuğu beslemek ve korumak zorunda olan erkeği sahiplenmeye iter onu. Dolayısıyla eşlerin sadakati erkekte tamamen yapay ve göstermelik, kadındaysa doğaldır." (K1zılkaya, 2005: 97-98).

Muhafazakâr düşünürler de muhafazakâr toplum yapısının korunması için çabalamışlardır. Mary Ward, Louise Creighteon, Elizabeth Wordworth ve Lucy Soulsby gibi muhafazakâr kadınlar, 
geleneksel cinsiyet rollerine meydan okumamak gerektiğini, bilakis toplumsal cinsiyet rollerinin gerekliliğini savunmuştur. Kadın ve erkeği birbirinden ayıran şeyin zayıflık olmadığını ileri süren söz konusu dört isim de kadınların kendine özgü rolleri için özel yetenekler veya güçlü yönler barındırdıkları anlayışı konusunda hemfikirdir. Kadının erkeğin rolünü üstlenmeye çalışması durumunda erkeğin işinde başarılı olamayacağı gibi kendi işini de düzgün yapamayacaktır. Yani, "kadın kadınlığını, erkek de erkekliğini bilerek dengeli ve tertipli bir toplum kurulmuş olacaktır" anlayışını benimsemişlerdir. Aynı zamanda kadınların eğitimi için büyük mücadele içerisinde olmuşlardır. Ancak bu mücadelenin amacı, "kadının toplumsal mukadder kılınmış rolünü pekiştirmek ve onun etkisini evrensel cinsiyet eşitliği üzerine tehlikeli iddialarda bulunmadan ziyadeleştirmek" olarak benimsemeleridir. Yani kadınlara verilecek olan eğitimin, özelde ve genelde kadının geleneksel rollerini layıkıyla yerine getirmesi amacına hizmet etmesi gerekliliği üzerinedir (Zülfikar ve İçener, 2014: 169-171). Kendilerine has yeteneklerini geliştirecek şekilde eğitilen kadınların, bu yeteneklerini ülkenin iyiliği için kullanmaları (Zülfikar ve İçener, 2014: 177) ve aldıkları eğitimle "tüketici” konumundan çıkarılıp "üretici” olarak topluma yararlı fertlere dönüşmeleri amaçlanmıştır. Bu nedenle kadınların eğitimi "başıboş, müsrif ve yeteneksiz kadınları verimli, yetenekli ve gayretli ev yöneticilerine dönüştürme çabası" olarak nitelendirildiğinden desteklenmektedir. "Ev yöneticisi olarak kadın" şeklinde sıklıkla vurgulanan bir tabirle kadının ev içinde üstlendiği sorumluluklar/ev yöneticiliği profesyonel bir meslek olarak lanse edilmekte ve kadınların eğitilmesine özellikle gelecek nesilleri yetiştirmeleri anlamında önem verilmektedir (Zülfikar ve İçener, 2014: 175-177).

Baver LaHaye'ye göre, Muhafazakâr kadınlar, her zaman kendi kimliklerini takdir etmiş ve bu kimliği korumak için mücadele içerisinde olmuşlardır. Bu kadınlar, erkeklere öykünme veya erkeklerle rekabet etme ihtiyaçlarının olmadıklarını ve erkeklerden benzersiz bir şekilde farklı olduklarını düşünmekte olup, ebedi ve geleneksel değerlere inandığını beyan etmiştir. Rush Limbaugh'un adlandırdığ 1 şekliyle cinsiyetler arasındaki farklılıkları ortadan kaldırma mücadelesi içerisinde olan “feminaziler"e rağmen, muhafazakârlar bu farklılıkları takdir eder ve bu farklılıkların, hayatın özünü oluşturduğunu düşünür. Muhafazakârlara göre kadının aile ve toplum içinde erkeklerden farklı rollerinin bulunması, onları erkeklerden daha az eşit bir konuma sokmamaktadır. Diğer bir ifadeyle, kadının aile sorumluluğu ile erkeğin kamusal alanda üstlendiği rol arasında önem açısından bir farklılık yoktur, kadın ve erkek "eşit ama farklıdır" anlayışı hâkimdir. Muhafazakâr düşünceye göre bunun aksini düşünenler, kadınların geleneksel rollerinin meydana getireceği etkiyi basit görmektedirler. (Demirel, 2013: 61-62; Heywood, 2011a: 256). Bu durumu Fox-Genovese şu şekilde ifade etmektedir: "Kadının hayatı, hem kendisi için hem de toplum için önemlidir" yani, kadınlar toplumsal refahın oluşmasında önemli rol oynamaktadırlar (Baehr, 2009: 106).

$\mathrm{Bu}$ yüzden kadınların erkeklere göre dezavantajlı, eşitsiz ve ikincil bir konumda olduğu, ezildiği, sömürüldüğü noktasından hareket ederek, mevcut olan bu durumu ortadan kaldırmak için, kadınların, kendilerini baskı altına alan bu düzeni algılama, politik olarak tanımlama ve ona karşı mücadele yöntemleri geliştirme amacıyla ortaya çıkan feminist harekete (Çakır, 2012: 415-416) 
muhafazakârlar pek sıcak bakmamışlardır. Feminist harekete sıcak bakmayan muhafazakâr kesimin çıkışları, genelde aile kurumunu korumaya yönelik olmuştur. Örneğin: Feminist taleplerin "reisi olmayan bir aile, çocuklara annenin de soyadı verilebilir ve buna benzer maddelerle hedef bizim sıcak aile yapımızdır" diye yorumlayan Ayla Ağabegüm, feminist hareketi aile kurumu için bir tehdit olarak görmektedir (Çelik, 2010: 142).

Kadına anne, eş, kız çocuğu rolünde değer verilmesi gerektiği anlayışını savunan muhafazakârlar, kadınların siyasal arenada görünmesine uzun süre direnmişlerdir. Muhafazakârlar, kadınların seçim kampanyalarına katılmak ve politik bir tutum içinde olmak gibi siyasallaşma eğilimlerinin onları kadınlıktan arındırma ve siyaseti kadınlaştırma gibi sorunlara neden olacağını düşünerek kadınların oy verme hakkına karşı çıkmışlardır (Nisbet, 2011: 83). Bu düşünce nedeniyle Hegel'in de ifade ettiği gibi, kendileri için öngörülen yazgı nedeniyle kadınlar erkekler gibi doğasını aşarak akıl ve özgürlük aracılığıyla tarihsel ve siyasal aktör olma sürecine dahil olamamıştır. Hegel'in siyaset felsefesine göre kadının en temel görevleri olan; aile içindeki yeniden-üretim, çocuk doğurma ve bakımı, erkeğin cinsel ve duygusal ihtiyacını tatmin etme gibi roller, kadının kamusal alana çıkması için bir engel olarak görülmektedir. Ayrıca bu görev/roller kadının tarih dışında kalmasını sağlayan önemli bir faktördür (Çaha, 2010: 41).

Başta muhafazakâr düşüncenin gelişiminde önemli rol oynayan Hegel olmak üzere, birçok muhafazakâr düşünür kadınların toplumsal rol ve konumlarının geleneksel çizgiden kopmaması gerektiğini ifade etmektedir. Benimsenen bu siyaset felsefesinde kadının yeri, üç etik alanın en yalın biçimi olan aile içinde formüle edilmiştir. Erkekler sivil toplumsal alana ve devlete aile ilişkileri faktöründen bağımsız bir şekilde varmaktayken, bu ilişki kadınlar için sınırlayıcı bir unsur olmuştur. Kadının kendisini dış dünyaya taşıyacak akıl potansiyelinden yoksun olduğu düşüncesi onları aile içinde kalması düşüncesini pekiştirmiştir. Hegel'e göre, devleti ve sivil toplumu geliştiren önemli bir unsur akıldır. Bu nedenle aklı erkeğe ait bir güç olarak gören Hegel, kamusal alanda eyleme ve devleti yönetme durumlarında temel rolü erkeğe verirken; duygusal bir yaradılışa sahip olan kadının rolünün aile içinde sürdürülebilir olduğunu öne sürer. Doğası gereği kadın yakınlı̆̆ı, doğallığı, özveriyi, şefkat ve sevgiyi barındırırken; erkek ise, evrenselliği, uzaklığı, özgürlüğü, bencilliği ve ayrışmayı barındırır (Çaha, 2010: 39). Muhafazakârlık denince akla gelen ilk isimlerden olan Edmun Burke’un özgürlüğü, "erkeksi, ahlaki ve kurallara bağlanmış bir özgürlük" (Beneton, 2011:24) olarak ele alması da bu yüzdendir. Muhafazakârlık ideolojisinin temel argümanlarını oluşturan düşünürlerin görüşlerinden özgürlük kavramı ile ilişkilendirilmeyen kadının, muhafazakâr siyaset anlayışındaki konumunun patriarkal anlayışıyla paralellik gösterdiği anlaşılmaktadır.

Patriarkal anlayışa göre, doğası gereği rasyonel zihinsel becerileriyle dünyayı yorumlama ve düzene sokma, hükmetme yeteneğine erkekler sahiptir. Buna karşın çocuk doğurma ve yetiştirme yeteneklerine sahip kadınlara günlük yaşamın ve türün yeniden üretilmesi rolü atfedilmiştir. $\mathrm{Bu}$ durumda her iki işlev önemli sayılmakla birlikte, erkeğin rolü aşkın kadınınki ise, içkin etkinliklere denk düşmektedir. Ancak kadının cinselliğini ve üreme yetisini kullanmasında denetim yetkisi kendisinde 
değil erkektedir (Berktay, 2009: 26-27). Hegel'e göre biçilen bu işbölümü, kadına evin bekçisi rolü, erkeğe de kamusal alanın motor görevi yüklemiştir ve bu iki alanın karşıllaştırılmasında ise, erkeğin üstünlügünü görmemiz mümkündür (Çaha, 2010: 40). Muhafazakâr düşüncede, kadınların toplumsal yaşamdaki konumunun, devrimci kopuşlarla değişimi şiddetle karşı çıkılan bir durumdur. Klasik kadınerkek rol dağılımında reformlarla da olsa herhangi bir değişiklik yapılması istenmemektedir. Muhafazakârlar kadının güzel ve masum anne olarak tanımlanan rolünü, özel mülkiyetin dokunulmazlığ 1 ve toplum içi hiyerarşinin gereğine atfedilen değerden daha fazla önemserler (Koç, 2012: 79). Bu durum "Değişemezsiniz zaten!" söyleminin zeminini oluşturmakta ve kadınlara "Değişmeyin!" deme gerekliliğini ortadan kaldırmaktadır (Koç, 2014: 28).

\section{SONUÇ}

Her düşünce yapısının toplum öğeleri üzerinde farklı boyutlarda etkileri olmaktadır. $\mathrm{Bu}$ bağlamda muhafazakâr düşünce de birçok toplumsal unsuru etkilemektedir. Ancak muhafazakâr düşüncenin kadının konumu ile ilişkisi etkilemekten ziyade biçimlendirme düzeyindedir ve bu Hume (1976)'un “doğanın iki cinse damgasını bastığı, sürekli ve düzenle olarak koruduğu farklı karakterleri..." ifadesinden anlaşılacağı üzere doğal bir durum olarak görülmektedir. Kadının konumu muhafazakâr düşüncenin din, gelenek, aile ve mülkiyet gibi temel öğelerinin doğrudan görünür olduğu bir alandir.

Muhafazakâr düşüncede kadın ve erkeğin rolleri, keskin bir şekilde ayrılmıştır. "Biyoloji kaderdir" anlayışından yola çıkan muhafazakâr düşünce, kadın-erkek rol dağılımında reformlarla da olsa herhangi bir değişiklik yapılmasını öngörmemektedir. Kadını erkeğe bağımlı olarak konumlandıran muhafazakâr düşünce, kamusal alanda dışladığı kadına "kadın tabiatına" uygun iş alanları ile yer vermektedir.

Muhafazakârlar tarafindan bir yazgıya mahkûm edilen kadın, toplumun temeli olarak görülen aile kurumu içerisinde türetilmiş ve onu bu kurum içine hapseden anne, eş, bacı ve kız rolleriyle kimlik kazandırılmaya çalışılmıştır. Siyasi, ekonomik ve idari alanlardan uzak tutulan kadın, sınırları erkek tarafından tayin edilen özel alan içerisinde erkeğin ve yetiştirmekle yükümlü tutulduğu çocukların tamamlayıcısı olarak yaşamını idame ettiren; neslin devam ettirilmesi hususunda önemli görülen, iffeti erkeklerce korunması ve anne olarak kutsanması gereken edilgen bir varlık olarak addedilmektedir. Biyolojik özellikleri ve kendisine yüklenen bu patriarkal rollerden dolayı kamusal alandan büyük ölçüde tecrit edilen bir varlığa dönüşmüştür. Kamusal alanda ise, hemşire, öğretmen, sekreter gibi kadın tabiatıyla uyumlu olarak görülen ve özel alanda kadının üstlendiği rollerin kamusal uzantısı olan işler kadınlara hasredilmiştir. Bu özellikleri nedeniyle muhafazakâr ideolojide feminizme karşı bir duruş ve patriarkal toplumsal yapının öngördüğ̈̈ toplumsal cinsiyet algısının bütün unsurları görülmektedir. 


\section{KAYNAKÇA}

Akıncı, M. (2012). Türk muhafazakârlı̆̆g: çok partili siyasal hayattan 12 eylül'e. Ankara: Ötüken Yayınları.

Akkaş, H. H. (2003). Muhafazakâr siyasi düşünce kavramı üzerine, Afyon Kocatepe Üniversitesi Sosyal Bilimler Dergisi, 5(2), 241-254.

Akkır, R. (2006). Türkiye'de din ve muhafazakarlı, Yayımlanmamış yüksek lisans tezi, Çukurova Üniversitesi Sosyal Bilimler Enstitüsü, Adana.

Aktan, Ç.C. (2007). Muhafazakârlık ve Liberal Düşünce. Köprü. Erişim Tarihi: 06 Ağustos $2017 \mathrm{http}: / /$ www.koprudergisi.com/index.asp?Bolum=EskiSayilar\&Goster=Yazi\&YaziNo=825.

Aytaç, A. M. (2015). Dünya görüşü ve ideoloji. Y. Taşkın, (Ed.), Siyaset: Kavramlar, Kurumlar ve Süreçler (105-137). İstanbul: İletişim Yayınları

Baehr, A R. (2009). Conservatism, feminism, and Elizabeth Fox Genovese. Hypatia, 24(2). 101-124.

Balta, E. (2012). Muhafazakârlaştırmanın gölgesinde: kadınların ikincil konumu pekişirken, Yeniyol, 45, 1-4.

Baradat, L. P. (2012). Siyasal ideolojiler: kökenleri ve etkileri. Abdurrahman Aydın (Çev.). Ankara: Siyasal Kitabevi.

Barry, N. P. (1989), Yeni săg. Cevdet Aykan (Çev.). Ankara: Tisamat.

Başterzi, A. D. (2013). Kadınların görünmeyen emeği, görünmeyen yorgun ruhları: Asiye nasıl kurtulur?. Feminist Politika, (17), 10-11.

Beneton, P. (2011). Muhafazakârlık. Cüneyt Akalın (Çev.). İstanbul: İletişim Yayınları.

Berktay, F (2009). Tek Tanrılı dinler karşısında kadın. İstanbul: Metis Yayınları.

Burke, E. (1951). Reflections on the revolution in France. London: Temple Press.

Ceylan, A. Y. (2007). Edmund Burke'ün "muhafazakâr" düşüncesinde "iyi devrim" "kötü devrim ayrımı”. Muhafazakar Düşünce (11), 23-44.

Çaha, Ö. (2004). Muhafazakâr düşüncede toplum. Liberal düşünce dergisi (34), 15-23

Çaha (2007). Dört akım dört siyaset. Ankara: Orion Kitabevi.

Çaha (2010). Sivil kadın türkiye'de kadın ve sivil toplum. Ankara: Savaş Yayınları.

Çakır, S. (2012). Feminizm: ataerkil iktidarın eleştirisi. H. Birsen Örs (Dü.), 19. yüzyıldan 20. yüzyıla modern siyasal ideolojiler (413-476). İstanbul: Bilgi Üniversitesi Yayınları.

Çelik, Ş. (2010). Kadın algısı ve kavramsal olarak kadın. Füsun Çoban Döşkaya (Ed.). 21. yüzyılın eşiğinde kadınlar değişim ve güçlenme uluslararası multidisipliner kadın kongresi (13-16 ekim 2009) bildiri kitabı (138-143), Cilt: 2, İzmir: Dokuz Eylül Üniversitesi Fen-Edebiyat Fakültesi Yayını,

Çetin, H. (2004). Muhafazakârlık: kaosa karşı kozmos. Muhafazakar düşünce (1), 87-119.

Davis, J. C. (2010). Taş devrinden bugüne tarihimiz insanın hikâyesi. Barış Bıçakçı (Çev.). İstanbul: Türkiye İş Bankası Kültür Yayınları. 
Demirel, E. (2013). Muhafazakârın tanımı. Ayşegül Akbay Yarpuzlu (Dü.). Muhafazakar mısınız yoksa liberal mi? (56-76), İstanbul: Cinius Yayınları.

Duman, F. (2010). Aydınlanma eleştirisinden devrim karşıtllğına Edmund Burke. İstanbul: Liberte Yayınları.

Duman, M. Z. (2012). Aile kurumu üzerine tarihsel bir okuma girişimi ve muhafazakâr ideolojinin aileye bakışı. İnsan Ve Toplum Bilimleri Araştırmaları Dergisi, 1 (4). 19-51.

Dural, A. B. (2004). Muhafazakârlığın tarihsel gelişimi ve muhafazakâr söylem. Muhafazakâr Düşünc,e (1), 121-133

Dural, A. B. (2006). Muhafazakârlık: düşünce kalıbı mı, ideoloji mi?. Muhafazakâr Düşünce, (9-10), 55-66.

Ergil, D. (1986a). İdeoloji “milliyetçilik, muhafazakârlık, halkçılık". Ankara: Sevin Matbaası.

Ergil, D. (1986b). Muhafazakâr düşüncenin temelleri muhafazakârlık ve yeni-muhafazakârlık. Ankara Üniversitesi SBF Dergisi 41(1), 269-292.

Frohnen, B. P. (2004). Law's culture: conservatism and the American constitutional order. Harward Journel of Law and Public Policy (27), 459-488.

Güler, E. Z. (2012). Muhafazakârlık: kadim geleneğin savunusundan faydacılı̆̆a. H. Birsen Örs (Dü.), 19. yüzyıldan 20. yüzyıla modern siyasal ideolojiler (116-162). İstanbul: Bilgi Üniversitesi Yayınları.

Güngörmez, B. (2004). Muhafazakâr paradigma: "dogma” ve “önyargı”. Muhafazakar Düşünce, (1), 11-30.

Heywood, A. (2011a). Siyasi ideolojiler. Şeyma Akın vd. (Çev.) Ankara: Adres Yayınları.

Heywood (2011b). Siyaset. B. Berat Özipek (Çev.) Ankara: Liberte Yayınları.

Hume, D. (1976). Insanın anlama yetisi üzerine bir soruşturma, Oruç Aruoba (Çev.). Ankara: Hacettepe Üniversitesi Yayınları.

Jones, E. (2017). Edmund Burke and the invention of modern conservatism, 1830-1914. Oxford: Oxford University Press.

Karatepe, Ş. (2011). Siyasi ideolojiler. İstanbul: İz Yayınc1lık.

Kaya, M. (2014). Kadın (Muhafazakar Düşünce Dergisi Makale Çağrısı). Erişim Tarihi: 05 Şubat 2014, http://www.muhafazakar.com/,.

Kızılkaya, H. (2005). Anasoyluluktan günümüze kadın. İzmir: İlya Yayınevi

Kirk, R (2008). Muhafazakârlı̆̆ın on prensibi. Okan Aslan, ve Cemal Fedayi (Çev.). Muhafazakâr Düşünce, (16-17), 243-250.

Koç, H. (2012). Muhafazakârlığa karşı feminizm. İstanbul: Destek Yayınevi.

Koç, H. (2014). Muhafazakârlığa karşı feminizm, Feminist Politika, (22), 28-29.

Köni , H., Torun, İ. (2013). Muhafazakârlık olgusu ve Amerika-Türkiye örneklerinde dini muhafazakârlık. Muhazakâr Düşünce, (38), 181-209. 
Letwin, S. R. (2012). Muhafazakâr bireycilik üzerine. Zehra Ulucak (Çev.). Muhafazakâr Düşünce, (32), 5-20.

Mollaer, F. (2008). Türkiye'de liberal muhafazakârlık ve Nurettin Topçu. İstanbul: Dergay Yayınları.

Muller, J. Z. (2000). Dilemmas of conservatism. Public Interest, 50-64.

Nisbet, R. (2011). Muhafazakârlık düş ve gerçek. Kudret Bülbül ve M. Fatih Serenli (Çev.). Ankara: Kadim Yayınları.

Oakeshott, M. (2004). Muhafazakâr olmak üzere. İsmail Seyrek (Çev.) Muhafazakâr Düşünce, (1), 55-78.

Özgün, Y. (2014). Muhafazakârlık: patriyarkaya her daim yandaş", Feminist Politika, (22), 1415.

Özipek, B. B. (2011). Muhafazakârlık: akı1, toplum, siyaset. İstanbul: Timaş Yayınları.

Özsel, D. (2012). Muhafazakârlık ve eşcinsellik: hastalık ve sağglkta.... Erişim Tarihi: 10 Aralık 2016, hffp://www.kaosgl.com/sayfa.php?id=12879,

Safi, İ. (2005). Türkiye'de Muhafazakârlı̆̆ın düşünsel-siyasal temelleri ve 'muhafazakâr demokrat' kimlik arayışları. Yayınlanmamış Doktora Tezi, Ankara Üniversitesi Sosyal Bilimler Enstitüsü, Ankara

Şeyhanlığlu, H. (2011). Türk siyasal muhafazakârlı̆̆ın kurumsallaşması ve Demokrat Parti. Ankara: Kadim Yayınları.

Tekin, Ü. (2004). AK Parti'nin muhafazakâr demokrat kimliği. Ankara: Orient Yayınları.

Tok, N. (2015). Siyasal ideolojiler. Halis Çetin (Ed.). Siyaset Bilimi (167-255). Ankara: Orion kitabevi

Türe, F. (2005). Muhafazakârlık, yeni sağ ve AKP. Eğitim Bilim Toplum, 3(12), 40-57.

Vural, M. (2003). Siyaset felsefesi açısından muhafazakârlık. Ankara: Elis Yayınları.

Winker, C. (2005). Women and conservatism after the sexual revolution. Society, 42(3), 18-24.

Yanardağ, M. (2004). Yeni muhafazakârlar (Neo-Cons). İstanbul: Chiviyazıları Yayınevi.

Yayla, A. (2004). Siyasi düşünceler sözlügü̈. Ankara: Adres Yayınları.

Yılmaz, A. (2001). Çağdaş siyasal akımlar. Ankara: Vadi Yayınları.

Yılmaz, H. (2005). Gelenek, gelenekçilik, gelenekselcilik. Muhafazakâr Düşünce (3), 39-53.

Zülfikar, Y., İçener, Z. (2014). Makale incelemesi: erken 20. yüzyılda kadınların eğitimi, toplumsal cinsiyet ve muhafazakarlık. Muhafazakâr Düşünce (41-42), 167-178. 